\title{
DEVELOPMENT AND TESTING OF A GREEN FLUORESCENT PROTEIN-BASED BACTERIAL BIOSENSOR FOR MEASURING BIOAVAILABLE ARSENIC IN CONTAMINATED GROUNDWATER SAMPLES
}

\author{
Vivian Hsiu-Chuan LiaO* and Kun-Lin Ou \\ Department of Bioenvironmental Systems Engineering, National Taiwan University, Taipei 106, Taiwan, Republic of China
}

(Received 6 October 2004; Accepted 13 January 2005)

\begin{abstract}
A green fluorescent protein (GFP)-based bacterial biosensor for the detection of bioavailable As(III), As(V), and Sb(III) was developed and characterized. The biosensor strain Escherichia coli DH5 $\alpha$ (pVLAS1) was developed based on the expression of $g f p$ under the control of the ars promoter and the arsR gene of Staphylococcus aureus plasmid pI258. Strain DH5 $\alpha$ (pVLAS1) responded mainly to $\mathrm{As}(\mathrm{III}), \mathrm{As}(\mathrm{V})$, and $\mathrm{Sb}(\mathrm{III})$, with the lowest detectable concentrations being $0.4,1$, and $0.75 \mu \mathrm{M}$, respectively, during a 2-h exposure and $0.1 \mu \mathrm{M}$ for all three metal ions with an 8-h induction period. To assess its applicability for analyzing environmentally relevant samples, the biosensor was field-tested on shallow-well groundwater for which contaminant levels were known. Our results demonstrate that the nonpathogenic bacterial biosensor developed in the present study is useful and applicable in determining the bioavailability of arsenic with high sensitivity in contaminated groundwater samples, and they suggest a potential for its inexpensive application in field-ready tests.
\end{abstract}

Keywords-Green fluorescent protein Bacterial biosensor Bioavailable arsenic Contaminated groundwater

\section{INTRODUCTION}

Concern is growing about the potential effects of environmental metal pollution on human health and the environment. With this awareness, a need for sensitive and effective methods that can efficiently monitor and determine the presence and amount of hazardous metals in the environment is being recognized. Among metals and metalloids, arsenic toxicity is considered to be an important issue of current public health. Arsenic, a known human carcinogen, is widely distributed in food, water, soil, and air. It is released into the environment from both natural and human activities [1]. It was ranked first on the Comprehensive Environmental Response, Compensation, and Liability Act priority list of hazardous substances in 2003 (http://www.atsdr.cdc.gov/clist.html). Arsenic is introduced into water through the dissolution of minerals and ores. In addition, arsenic can accumulate in groundwater and well water in some areas as a result of erosion or leaching from local rocks. Moreover, industrial effluents, combustion of fossil fuels, and arsenic pesticides all contribute to arsenic contamination in freshwater systems [1]. Exposure to arsenic in drinking water represents a significant health problem for people around the world. Epidemiologic studies in Taiwan, Chile, Bangladesh, and India have shown that arsenic exposure is associated with skin, liver, lung, bladder, and other cancers [2-4].

Several different types of organic and inorganic arsenic exist. The inorganic arsenics, including arsenite (As(III)) and arsenate $(\mathrm{As}(\mathrm{V}))$, can be methylated to form monomethylarsonic acid and dimethylarsinic acid in vivo [5]. The toxicological effects of arsenic highly depend on its oxidation state, chemical composition, and bioavailability [6]. The trivalent

* To whom correspondence may be addressed (vivianliao@ntu.edu.tw). form of arsenic appears to be the most toxic, regardless of its being inorganic or organic form [7].

In contrast to arsenic, antimony is less widely distributed in the environment. Nevertheless, it was found to be an environmental contaminant because of anthropogenic activities. Mining and smelting operations are the greatest emission source of antimony into the environment [8]. Additionally, antimony is used in semiconductors for making infrared detectors, diodes, and Hall-effect devices [9]. Antimony trioxide is used primarily as a flame-proof retardant of textiles, plastics, paint pigments, adhesives, and paper [9]. Antimony potassium tartrate has been used worldwide as an antishistosomal drug. Pentavalent antimony compounds are used widely in the treatment of leishmaniasis [10].

Antimony has no known biological function, and like arsenic, it is toxic. Little work has been done regarding the toxicology of antimony, because it is less widely present in the environment. Therefore, little information about antimony is available for evaluating its toxicology and accurately determining its impact on the environment and human health. As with arsenic, antimony bioavailability and toxicity are dependent on speciation $[11,12]$.

Certain microorganisms have evolved and contain the necessary genetic components that confer a variety of resistance mechanisms that allow them to survive and grow in environments containing levels of metals that would be toxic to most organisms. Resistance to $\mathrm{As}(\mathrm{III}), \mathrm{As}(\mathrm{V})$, and $\mathrm{Sb}(\mathrm{III})$ is found in both Gram-negative and Gram-positive bacteria [13]. Highlevel resistance to arsenic is conferred by the ars operon. Bacterial ars systems confer arsenic resistance primarily by encoding a specific efflux pump that exports As(III) from the cytoplasm, thus lowering the intracellular concentration of the toxic arsenic [14,15]. The arsenic resistance ars operon in Escherichia coli has both plasmid [16] and chromosomal [17] determinants. The well-characterized plasmid-borne ars op- 
eron of E. coli is composed of two regulatory genes (arsR and $\operatorname{ars} D)$ and three structural genes ( $\operatorname{ars} A, \operatorname{ars} B$, and $\operatorname{ars} C)$ $[18,19]$. In contrast, the ars operon in plasmid pI258 of Staphylococcus aureus contains only one regulatory gene, $\operatorname{ars} R$, as well as two structural genes, $\operatorname{ars} B$ and $\operatorname{ars} C$ [20]. In the absence of $\mathrm{As}(\mathrm{III})$, the $\operatorname{ars} R$ repressor binds to its operator/promoter site within the operon and, therefore, prevents the expression of the structural genes [20]. In the presence of As(III), it interacts with the repressor, leading to a conformational change that results in the dissociation of ars $R$ repressor from its operator/promoter site [20]. Consequently, the downstream ars genes express, and detoxification occurs.

Because of the precise regulation of the resistance gene expression, the regulatory element can then be coupled to a reporter gene through a gene fusion that, upon expression, produces a readily measurable signal in response to toxic metals and metalloids. Several bacterial biosensors based on transcriptional fusions between arsenic-inducible promoters and reporter systems have been described [21-24]. These biosensing systems are based mostly on the resistance mechanism that is encoded by the ars operon found on the E. coli plasmid R773 [21-23]. In contrast, Tauriainen et al. [24] employed a different regulatory unit that was derived from the ars operon of plasmid pI258 from $S$. aureus. Various reporter genes, such as $l a c Z$, $l u x A B$, and $l u c$, were used in the transcriptional fusion constructs in their studies [21-24]. Although the colorimetric enzyme assay and bioluminescence have been very successful as a reporter for arsenic detection in their studies, these detection methods require addition of exogenous substrates or cofactors for signal production. The gene for green fluorescent protein (GFP) from the jellyfish Aequoria victoria [25] is increasingly used as a reporter gene, although it has not been used extensively as a reporter for measuring biologically relevant concentrations of pollutants. Green fluorescent protein fluorescence is stable and can be monitored noninvasively in living cells. Green fluorescent protein also is an attractive reporter system, because it is easy to use and does not require any exogenous substrates or cofactors. The use of GFP as a reporter protein in the bacterial biosensing system therefore can obviate centrifugation, cell lysis, $\mathrm{pH}$ adjustment, and subsequently, kinetic enzyme activity measurements. Recently, Stocker et al. [23] developed a set of sensors that employed the regulatory units derived from the ars operon of $E$. coli plasmid $\mathrm{R} 773$ by fusing three reporter genes: lacZ, luxAB, or $g f p$. In their study, the GFP fluorescence levels in single cells were determined by epifluorescence microscopy, a procedure that was relatively time-consuming and might have hindered the biosensors from rapid detection and quantitation of arsenic.

In the present study, we describe the construction of a nonpathogenic $E$. coli whole-cell biosensor for the detection of bioavailable $\mathrm{As}(\mathrm{III}), \mathrm{As}(\mathrm{V})$, and $\mathrm{Sb}(\mathrm{III})$ by employing redshifted GFP ( $r s$-GFP) as a reporter protein. The sensor plasmid is based on the expression of $r s$-GFP under the control of the ars promoter and the ars $R$ gene of the $S$. aureus plasmid $\mathrm{pI} 258$ [20]. In the absence of $\mathrm{As}(\mathrm{III}), \mathrm{As}(\mathrm{V})$, and $\mathrm{Sb}(\mathrm{III})$, the expression of $g f p$ gene is repressed. In the designed sensor plasmid, ars $R$ regulates the expression of $g f p$ gene in a manner that is dependent on the concentration of As(III), As(V), and $\mathrm{Sb}$ (III) in the sample. Therefore, the fluorescence emitted by GFP is correlated to the concentration of As(III), As(V), and $\mathrm{Sb}$ (III) in the samples. Moreover, the levels of GFP fluorescence can be measured both rapidly and easily using fluorometry for assessing the bioavailability of $\mathrm{As}(\mathrm{III}), \mathrm{As}(\mathrm{V})$, and
$\mathrm{Sb}(\mathrm{III})$. Finally, although the biosensors described by others have been used successfully to detect arsenic, most of these biosensors often are not applied outside the research laboratory. Therefore, the feasibility of the bacterial biosensor for measuring bioavailable arsenic in environmental samples has not been well tested. To demonstrate the usability of the biosensor, we describe the use of the sensor to measure bioavailable concentrations of arsenic in arsenic-contaminated groundwater samples obtained from the blackfoot disease region in Taiwan. The feasibility of using such a strain to analyze the bioavailability of pollutants in the environment is also discussed.

\section{MATERIALS AND METHODS}

\section{Materials}

Sodium m-arsenite, sodium arsenate, cadmium chloride, cupric sulfate, cobalt chloride, mercuric chloride, manganese chloride, nickel chloride, ferrous sulfate, zinc chloride, sodium selenite, sodium selenate, potassium chromate, potassium permanganate, and potassium hexahydroxoantimonate were purchased from Sigma (St. Louis, MO, USA). Lead nitrate and potassium antimonyl L-tartrate hydrate were obtained from Sigma-Aldrich (St. Louis, MO, USA). All chemicals used were of analytical reagent grade or better. All media and buffer solutions were prepared using deionized (Barnstead, Dubuque, IA, USA) distilled water. Restriction endonucleases and T4 DNA ligase were supplied from New England Biolabs (Beverly, MA, USA). The DNA polymerase used in polymerase chain reaction (PCR) was from Qiagen (Hilden, Germany).

\section{Construction of biosensor plasmid}

Transcriptional fusions were constructed by directional cloning of the PCR-amplified promoter region DNA from plasmid pI258 into the multiple cloning site of the promoterless $r s$-GFP plasmid pPROBE-NT' ${ }^{\prime}$ [26]. Plasmid pI258 isolated from $S$. aureus (NCTC 50581; National Collection of Type Cultures, Colindale, London, UK) was used as a template for PCR to generate the DNA fragment consisting of the promoter/ operator of the arsR operon and arsR gene. The PCR primers were designed with either EcoRI (forward primer) or BamHI (reverse primer) recognition sequence extensions (underlined). Sequences of PCR primers were as follows: Forward, 5'CCGGAATTCTAAAATAACATAGACAATAATCT-3'; and reverse, 5'-CGCGGATCCCATCAACAGTCACCTGATT-3'. The size of the target amplicon was 380 base pairs. The DNA amplification was carried out in an automated thermal cycler (Eppendorf, Hamburg, Germany) with a 5-min denaturation step at $94^{\circ} \mathrm{C}$, followed by 30 cycles of denaturation at $94^{\circ} \mathrm{C}$ for $1 \mathrm{~min}$, annealing at $55^{\circ} \mathrm{C}$ for $1 \mathrm{~min}$, and extension at $72^{\circ} \mathrm{C}$ for $90 \mathrm{~s}$. After 30 cycles, a final extension was performed at $72^{\circ} \mathrm{C}$ for $15 \mathrm{~min}$ followed by a $4^{\circ} \mathrm{C}$ incubation. The amplified PCR product was purified using a QIAquick PCR purification kit (Qiagen). The purified PCR-amplified DNA fragment was digested with EcoRI and BamHI and was purified from an agarose gel by QIAII gel extraction kit (Qiagen). Subsequently, the fragment was cloned into the EcoRI and BamHI sites of pPROBE-NT'. The resulting recombinant plasmid, pVLAS1 (Fig. 1), was transformed into E. coli $\mathrm{DH} 5 \alpha$ by the $\mathrm{CaCl}_{2}$ competent cell method.

\section{Cultivation of bacteria and induction of GFP fluorescence} by effectors

A single colony of $E$. coli harboring pVLAS1 was grown overnight in Luria-Bertani (LB) medium supplemented with 


\section{EcoRI BamHI}

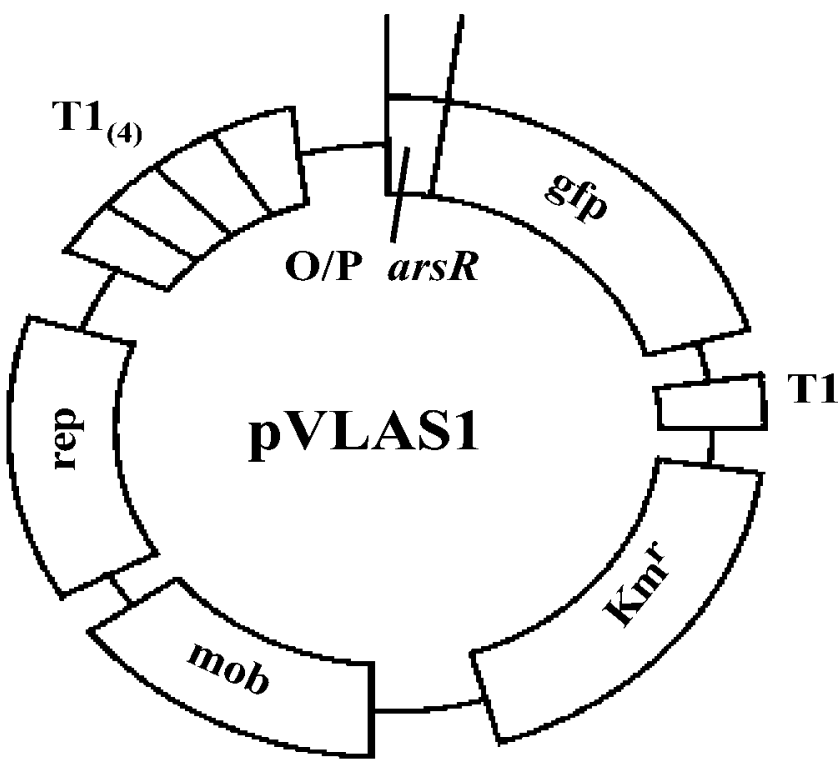

Fig. 1. Schematic organization of the biosensor plasmid pVLAS1. Plasmid harbors genes required for replication (rep) and mobilization (mob). The diagram is not drawn to scale. $\mathrm{km}^{\mathrm{r}}=$ gene encoding kanamycin resistance; $\mathrm{T} 1=$ Escherichia coli $r r n B$ rRNA $\mathrm{T} 1$ terminator; $\mathrm{gfp}=$ green fluorescent protein.

$50 \mu \mathrm{g} / \mathrm{ml}$ of kanamycin at $37^{\circ} \mathrm{C}$. The overnight culture was diluted 100-fold in fresh LB medium supplemented with 50 $\mu \mathrm{g} / \mathrm{ml}$ of kanamycin and incubated at $37^{\circ} \mathrm{C}$ in an orbital shaker at $225 \mathrm{rpm}$ until the optical density at $600 \mathrm{~nm}$ reached 0.6. Various concentrations of $\mathrm{As}(\mathrm{III}), \mathrm{As}(\mathrm{V})$, or $\mathrm{Sb}$ (III) were added to $20-\mathrm{ml}$ aliquots of bacterial cultures. Optical density of cultures at $600 \mathrm{~nm}$ and the fluorescent intensity produced by the bacteria were measured. At least three independent experiments were performed for each effector.

\section{Measurement of GFP fluorescence in culture}

The transcriptional activity of the biosensor was estimated by the measurement of the GFP fluorescence of cells grown in LB medium containing a range of different metal ions. Cell growth was monitored by the measurement of optical density at $600 \mathrm{~nm}$ with a spectrophotometer (Eppendorf). The fluorescence of GFP-producing cells that were grown in culture was measured using a VersaFluor Fluorometer (Bio-Rad, Hercules, CA, USA). The excitation wavelength of the fluorometer was set at $490 / 10 \mathrm{~nm}$, and the emission wavelength was set at $510 / 10 \mathrm{~nm}$. Escherichia coli DH5 $\alpha$ carrying pPROBE-NT' without the promoter/operator of the arsR operon and ars $R$ gene was used as the baseline sample to zero the instrument. Raw fluorescence values were expressed in the instrument's arbitrary relative fluorescent units. The specific fluorescence intensity (SFI) is defined as the raw fluorescence intensity expressed in relative fluorescence units divided by the optical density at $600 \mathrm{~nm}$ measured at each time point. At least triplicate measurements were obtained for each sample.

\section{Microscopic detection of biosensors}

The fluorescence of the bacterial cells cultured in LB medium containing metal ions was visualized by analysis of digital images captured with a Leica model DMIRB/E microscope (Leica Microsystems, Wetzlar, Germany) equipped for epifluorescence. The GFP fluorescence was detected with a GFP En- dow filter set (Chroma Technology, Brattleboro, VT, USA) fitted with excitation $(480 \pm 20 \mathrm{~nm})$ and emission $(510 \pm 20$ $\mathrm{nm})$.

\section{Selectivity studies}

The induction of the sensing system by a variety of metal ions, including $\mathrm{As}(\mathrm{III}), \mathrm{As}(\mathrm{V}), \mathrm{Sb}(\mathrm{III}), \mathrm{Sb}(\mathrm{V}), \mathrm{Cd}(\mathrm{II}), \mathrm{Co}(\mathrm{II})$, $\mathrm{Cu}(\mathrm{II}), \mathrm{Fe}(\mathrm{II}), \mathrm{Hg}(\mathrm{II}), \mathrm{Mn}(\mathrm{II}), \mathrm{Mn}$ (VII), Ni(II), Pb(II), Sn(II), $\mathrm{Zn}(\mathrm{II}), \mathrm{Cr}(\mathrm{VI}), \mathrm{Se}(\mathrm{IV})$, and $\mathrm{Se}(\mathrm{VI})$, was studied by measuring the green fluorescence produced. The response of the bacterial biosensor to the mixtures of metal ions also was investigated. For each metal ion, $1 \mu \mathrm{M}$ was added to bacterial sensor culture at a cell density of 0.6 optical density at $600 \mathrm{~nm}$. The cells were incubated for $2 \mathrm{~h}$ at $37^{\circ} \mathrm{C}$, and then the SFI was measured as described above. At least three independent experiments were performed for each kind of metal-ion and mixture-ofmetal-ions assays.

\section{Time-dependent induction of green fluorescence with effectors}

A metal-bacteria mixture was obtained using the protocol described above. The mixture was incubated in an orbital shaker at $225 \mathrm{rpm}$ at $37^{\circ} \mathrm{C}$. Optical density at $600 \mathrm{~nm}$ and fluorescence were measured at the beginning of and after the desired incubation period. At least three independent experiments were performed for each effector.

\section{Testing of contaminated groundwater}

Groundwater samples were collected from wells YL6 and YL7, which are known to have arsenic contamination, in YunLin County, Taiwan, Republic of China, in July 2003. The well water was tested by adding $500 \mu \mathrm{l}$ of groundwater sample to $250 \mu \mathrm{l}$ of $6 \times$ concentrate of LB medium, $10 \mu \mathrm{l}$ of LB medium, and $740 \mu \mathrm{l}$ of DH5 $\alpha$ cells harboring the pVLAS 1 plasmid in LB medium at a cell density of 0.6 optical density at $600 \mathrm{~nm}$. The cells were incubated for $2 \mathrm{~h}$ at $37^{\circ} \mathrm{C}$, and then the SFI was measured using the procedures described above. Samples containing known concentrations of As(III) in place of the $10-\mu 1$ portion of LB medium were tested in parallel with $500 \mu \mathrm{l}$ of deionized, distilled laboratory water in place of well water to generate a standard curve. The standard curve was derived from linear regression of the average fluorescence value at each particular As(III) concentration, and then the concentrations of $\mathrm{As}(\mathrm{III})$ in the groundwater samples were calculated from the standard curve. To examine possible inhibitory effects on fluorescence resulting from chemicals other than the effector compounds in the groundwater sample, $4 \mu \mathrm{M}$ As(III) was added to the groundwater sample, and the green fluorescence emission was compared to that for a positive control containing the same concentration of As(III) in deionized water.

\section{Data analysis}

The experiments were performed at least three times for error analyses. The data were used to calculate the standard deviations, which are represented by error bars in the figures. Student's $t$ test analysis at the $\alpha=0.05$ level was performed to check results for significance. Standard curve fits were done by linear regression analysis.

\section{RESULTS}

\section{Development of the bacterial biosensor}

The ars promoter and the arsR gene of $S$. aureus plasmid pI258 were cloned into the broad-host-range vector pPROBE- 


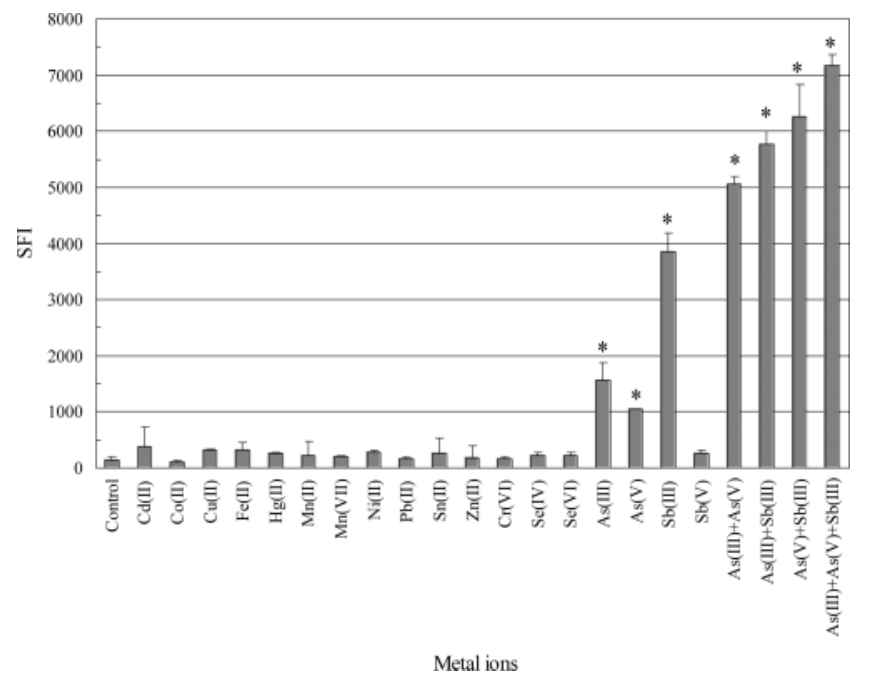

Fig. 2. Selectivity of the bacterial biosensor to metal ions. DH5 $\alpha$ (pVLAS1) was treated with $1 \mu \mathrm{M}$ of various individual metal ions or mixtures of metal ions for $2 \mathrm{~h}$. Fluorescence (in specific fluorescent intensity [SFI]) was measured with a fluorometer is defined as culture fluorescence divided by culture at a cell optical density at $600 \mathrm{~nm}$. Fluorescence (in SFI) was measured as described in Materials and Methods. Control refers to no-metal treatment biosensor bacteria. The data presented here are the mean values of three independent experiments with the standard deviations. ${ }^{*} p<0.05$.

$\mathrm{NT}^{\prime}$ [26] upstream from the $g f p$ gene, creating a $\mathrm{P}_{\text {ars }}-g f p$ transcriptional fusion that was designated pVLAS1, as shown in Figure 1. The $\mathrm{P}_{\text {ars }}-g f p$ fusion was flanked by $\mathrm{T} 1$ transcriptional terminators from the E. coli rrnBl operon to reduce the background level of expression caused by external transcription, thereby increasing the sensitivity of the vector [26,27]. In the presence of an effector, recombinant plasmid pVLAS1 in strain DH5 $\alpha$ resulted in a statistically significant increase in the fluorescence intensity relative to that of cells with no-effector control.

\section{Selectivity of biosensor to metal ions}

The selectivity of the bacterial biosensor to metal ions was evaluated. The bacterial cells harboring pVLAS1 plasmid were treated with $1 \mu \mathrm{M}$ of various metal ions for $2 \mathrm{~h}$ before fluorescence measurements, as described in Materials and Methods. The levels of fluorescence of the sensing system subjected to these metal ions also are plotted in Figure 2. In our experimental treatments, a positive response was observed for As(III), As(V), and Sb(III). No statistically significant change in green fluorescence was observed for $\mathrm{Sb}(\mathrm{V}), \mathrm{Cd}(\mathrm{II}), \mathrm{Co}(\mathrm{II})$, $\mathrm{Cu}(\mathrm{II}), \mathrm{Fe}(\mathrm{II}), \mathrm{Hg}$ (II), Mn(II), Mn(VII), Ni(II), Pb(II), Sn(II), $\mathrm{Zn}(\mathrm{II}), \mathrm{Cr}(\mathrm{VI}), \mathrm{Se}(\mathrm{IV})$, and $\mathrm{Se}(\mathrm{VI})$ compared to the control, as shown in Figure 2. The response of biosensor to metal ions also was examined by fluorescence microscopy. Results of fluorescence microscopy demonstrated that noticeable GFP expression was observed in the presence of $\mathrm{As}(\mathrm{III}), \mathrm{As}(\mathrm{V})$, and $\mathrm{Sb}$ (III) compared to that of the control (Fig. 3). The level of green fluorescence for cells treated with other metal ions other than the aforementioned metal ions was not significantly different from that of control under microscopic examination.

Metal species in the environment often exist as mixtures. Therefore, the response of the bacterial biosensing system to the mixtures of the present metals was investigated. To examine this potentially complex situation, we performed pairwise metal assays with the biosensor. For each metal ion, 1

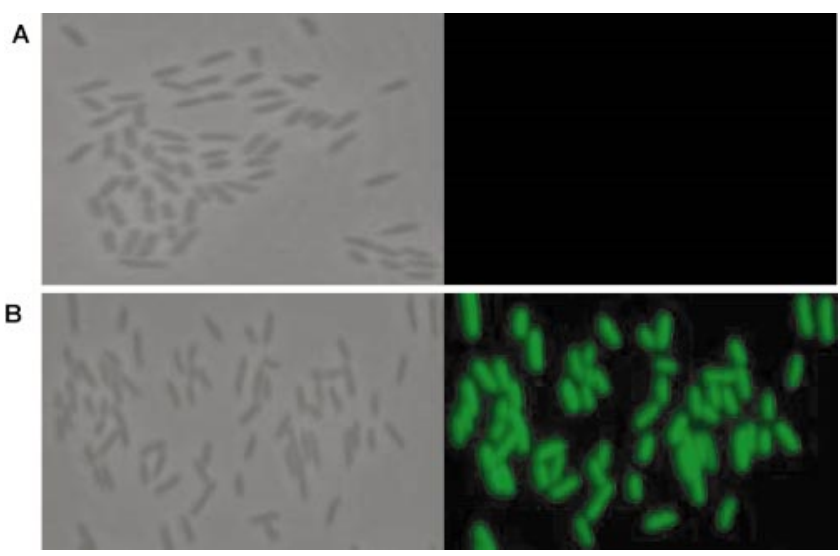

Fig. 3. Fluorescence of biosensor exposed to As(III). Expression of green fluorescent protein under control of the ars promoter was induced by adding $1 \mu \mathrm{M}$ As (III) for $2 \mathrm{~h}$ at $37^{\circ} \mathrm{C}$ in Luria-Bertani (LB) medium, after which green fluorescent protein expression in bacterial cells was visualized by using an Axiophot epifluorescence microscope. Images were captured by using a cooled charge-coupled device (CCD) camera. (A) Control (no As(III) treatment). (B) Bacterial cells treated with As(III). Left, visible microscopy; right, fluorescence microscopy. Magnification, $\times 1000$.

$\mu \mathrm{M}$ was combined in the same treatment. Additionally, the response from mixtures of $\mathrm{As}(\mathrm{III}), \mathrm{As}(\mathrm{V})$, and $\mathrm{Sb}(\mathrm{III})$ also was examined. As shown in Figure 2, the bacterial biosensor appeared to have a synergistic response to As(III) and As(V), as they coexisted in the test solution. An additive response was observed by the combinations of $\mathrm{As}(\mathrm{III})$ and $\mathrm{Sb}(\mathrm{III}), \mathrm{As}(\mathrm{V})$ and $\mathrm{Sb}(\mathrm{III})$, and $\mathrm{As}(\mathrm{III})$ and $\mathrm{As}(\mathrm{V})$ and $\mathrm{Sb}(\mathrm{III})$ (Fig. 2). The level of green fluorescence for cells treated with metal combinations other than the aforementioned combinations was not significantly different from that of control or effector alone (data not shown).

\section{Time-dependent induction of green fluorescence with effectors}

The induction of the bacterial sensor in response to As(III), $\mathrm{As}(\mathrm{V})$, and $\mathrm{Sb}(\mathrm{III})$ ion was determined by incubating the cells with metal ions for various time intervals, as described in Materials and Methods. The induction of green fluorescence of the DH5 $\alpha$ (pVLAS1) strain toward the exposure of these metal ions showed a time dependence (Fig. 4). As shown in Figure 4, the green fluorescence emitted by the bacteria increased as the incubation times with the metal ions increased. The background fluorescence exhibited by the untreated biosensors did not have any statistically significant fluorescent change during the incubation period. The kinetic profile of the biosensor response showed that during the first 5 to $6 \mathrm{~h}$ of incubation, the SFI continuously increased from the background value (Fig. 4).

\section{Dose-dependent induction of green fluorescence with effectors}

The dose-response relationship of $\mathrm{DH} 5 \alpha$ cells harboring the pVLAS1 plasmid was examined for the effectors As(III), $\mathrm{As}(\mathrm{V})$, and $\mathrm{Sb}(\mathrm{III})$, as described in Materials and Methods. The response of DH5 $\alpha$ cells harboring the pVLAS1 plasmid toward $\mathrm{As}(\mathrm{III}), \mathrm{As}(\mathrm{V})$, and $\mathrm{Sb}(\mathrm{III})$ was time dependent, as described above. A 2-h induction time was chosen to plot dose-response curves, because it yielded a sufficiently high fluorescent signal while maintaining a relatively short assay 


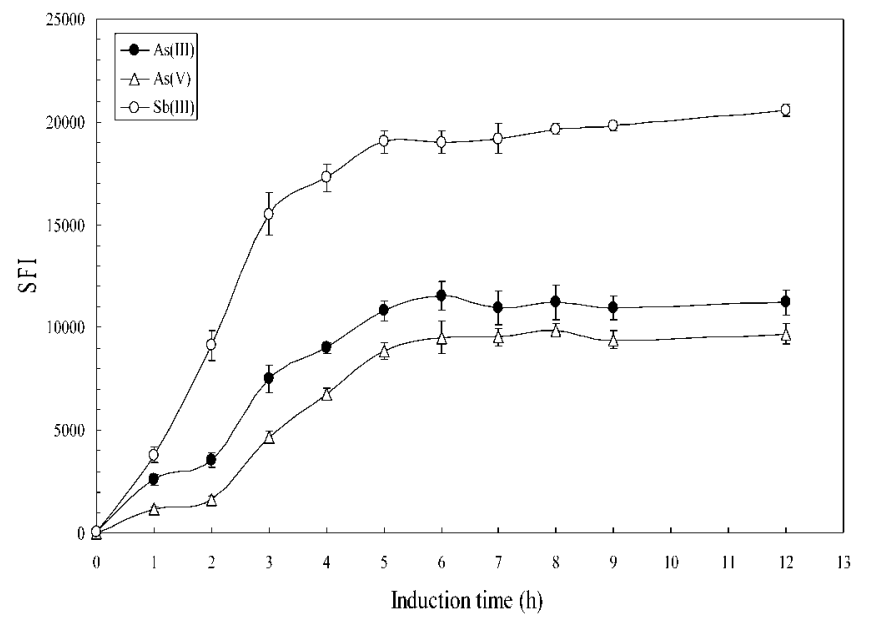

Fig. 4. Time-dependent induction of green fluorescence with effectors. The DH5 $\alpha$ cells harboring the pVLAS 1 plasmid were exposed to 4 $\mu \mathrm{M}$ As(III), As(V), or Sb(III), and the specific fluorescence intensity (in SFI) was determined after different exposure periods. Fluorescence (in SFI) measured with a fluorometer is defined as culture fluorescence divided by culture at a cell optical density at $600 \mathrm{~nm}$. The data presented here are the mean values of three independent experiments with the standard deviations.

time. Plots of the dose-response relationships of the biosensor to these effectors as measured with a fluorometer are shown in Figure 5. The intensity of fluorescent signal emitted increased with the concentration of As(III), As(V), and Sb(III). At concentrations lower than the detection limit of an effector, binding of arsR to the ars $\mathrm{O} / \mathrm{P}$ sequence repressed transcription and translation of $r s$-GFP. For As(III), $0.4 \mu \mathrm{M}$ As(III) was necessary to induce a statistically significant change $(p<0.05)$ of $g f p$ expression. The intensity of GFP increased with increasing amount of As(III) to a concentration of $10 \mu \mathrm{M}$. When the As(III) concentration increased to levels greater than 25 $\mu \mathrm{M}$, the fluorescence started to decrease. This might be caused

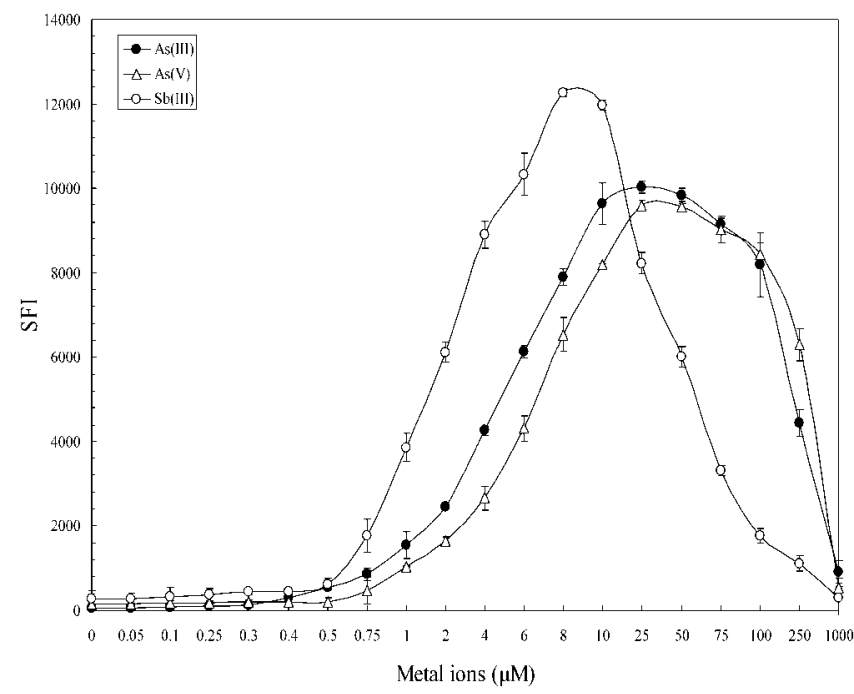

Fig. 5. Dose-dependent induction of green fluorescence by effectors. Fluorescence from DH5 $\alpha$ cells harboring the pVLAS1 plasmid was determined after 2-h incubation with various concentrations of metal ions, as described in Materials and Methods. Fluorescence (in specific fluorescence intensity $[\mathrm{SFI}]$ ) measured with a fluorometer is defined as culture fluorescence divided by culture at a cell optical density at $600 \mathrm{~nm}$. The data presented here are the mean values of three independent experiments with the standard deviations.

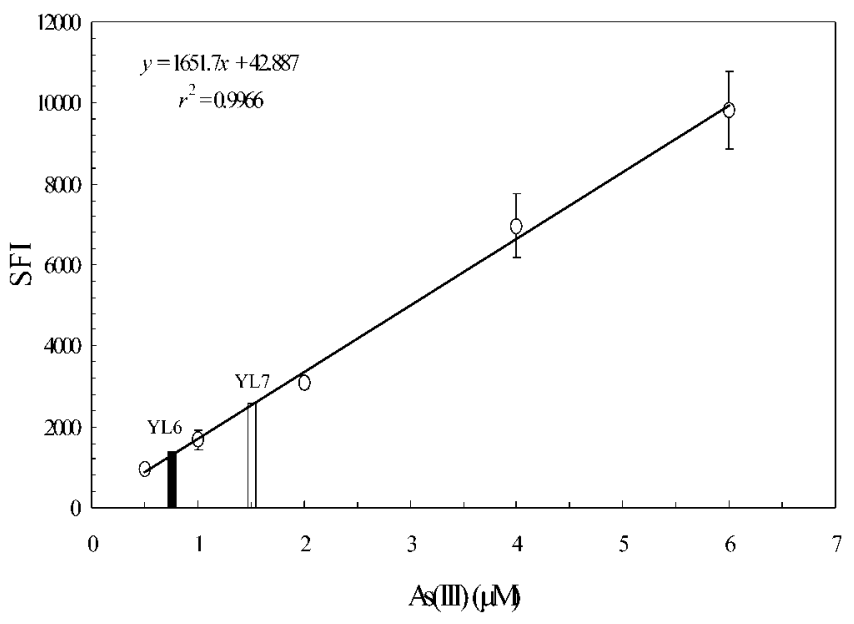

Fig. 6. Testing of contaminated groundwater by using the biosensor. Groundwater from arsenic-contaminated wells YL6 and YL7 in YunLin County, Taiwan, Republic of China was tested for arsenic contamination as described in Materials and Methods. Green fluorescence from $\mathrm{DH} 5 \alpha$ cells harboring the pVLAS1 was measured at various As(III) concentrations to generate a standard curve. The standard curve was generated by linear regression, and the resulting equation $\left(y=1651.7 x+42.887, r^{2}=0.9966\right)$ was used to calculate the As(III) equivalent concentration of the well water. The fluorescent response to groundwater from YL6 (black bar) and YL7 (white bar) is shown, as is the fluorescent response to different known As(III) concentrations (O). The data presented here are the mean values of three independent experiments with the standard deviations. SFI = specific fluorescence intensity.

by the toxicity of As(III) ions to the bacterial cells. For As(V), $1.0 \mu \mathrm{M}$ was necessary to induce a statistically significant change $(p<0.05)$ of $g f p$ expression, but $25 \mu \mathrm{M}$ caused a maximum $g f p$ induction. For $\mathrm{Sb}(\mathrm{III})$, the lowest concentration required to induce a statistically significant change $(p<0.05)$ of $g f p$ expression was $0.75 \mu \mathrm{M}$. At $8 \mu \mathrm{M} \mathrm{Sb}(\mathrm{III}), g f p$ expression was induced to a maximal level. Toxic effects were noted for $\mathrm{As}(\mathrm{V})$ and $\mathrm{Sb}(\mathrm{III})$ at concentrations greater than 75 and $10 \mu \mathrm{M}$, respectively. The sensitivity of the biosensing system was contingent on the exposure time of the metals used for inducing the cells. When the induction time was increased to $8 \mathrm{~h}$, the lowest detection limit for As(III), As(V), and $\mathrm{Sb}(\mathrm{III})$ was $0.1 \mu \mathrm{M}$.

\section{Testing of contaminated groundwater with the biosensor}

To demonstrate the utility of this biosensor in measuring actual environmental contamination, groundwater samples with a known contaminant concentration were examined, and the results of the biosensor assays were compared to these known concentrations. Groundwater was obtained from contaminated wells in the blackfoot disease region of Yun-Lin County. These wells have been actively monitored for arsenic pollution by the Industrial Development Bureau of Ministry of Economic Affairs (MOEA) for the past 12 years. Two particularly shallow wells, denoted as YL6 and YL7, respectively, have been reported to be contaminated principally with arsenic. Groundwater from wells YL6 and YL7 was tested by using the DH5 $\alpha$ (pVLAS1) biosensor. The standard curve generated by this test is shown in Figure 6, and the resulting equation that was used to calculate the As(III) equivalent concentrations of the well water is shown. Water from YL6 and YL7 gave a SFI of 1,252 \pm 364 (mean \pm standard deviation, $n=3$ ) and $2,508 \pm 99$, respectively. By calculating the contaminant concentrations from the standard curve, $0.73 \pm 0.22 \mu \mathrm{M}$ for YL6 
Table 1. Comparison of contamination concentrations from the groundwater of YL6 and YL7 well in Yun-Lin County, Taiwan, Republic of China

\begin{tabular}{cccc}
\hline Source & Well & \multicolumn{1}{c}{ Compound } & Concentration (ppb) \\
\hline MOEA $^{\text {a }}$ & YL6 & Total arsenic & 218 \\
& YL7 & Total arsenic & 362 \\
This & & & \\
study & YL6 & As(III) equivalent & $165 \pm 49.50(2.20 \pm 0.66 \mu \mathrm{M})$ \\
& YL7 & As(III) equivalent & $336 \pm 13.50(4.48 \pm 0.18 \mu \mathrm{M})$ \\
\hline
\end{tabular}

${ }^{\mathrm{a}}$ MOEA $=$ Ministry of Economic Affairs.

and $1.49 \pm 0.06 \mu \mathrm{M}$ for YL7 were obtained. Taking the dilution factor of the assay into account (see Materials and Methods), the final concentrations of contaminants in the groundwater were $2.20 \pm 0.66 \mu \mathrm{M}$ for YL6 and $4.48 \pm 0.18$ $\mu \mathrm{M}$ for YL7. Additionally, possible inhibitory effects that might be caused by chemicals other than the effector compounds in the groundwater sample also were assessed by spiking the sample with a known concentration of As(III) $(4 \mu \mathrm{M})$. Subsequently, the total SFI was measured and then compared to that for a positive control containing the same concentration in deionized water. No inhibitory effect was detected. Therefore, it is unlikely that the constituents other than the effector compounds in the groundwater samples interfered with GFP fluorescence.

Table 1 compares the results of YL6 and YL7 water testing conducted by the MOEA with the biosensor assay. Same batches of the groundwater samples were analyzed by the biosensor assay and the MOEA. The values obtained with the biosensor compare well to the data obtained by the MOEA.

\section{DISCUSSION}

\section{Development of arsenic GFP-based bacterial biosensor}

In the present study, we describe the construction and testing of a GFP whole-cell biosensor for the measurement of bioavailable arsenic from contaminated groundwater. The sensor plasmid, designated as pVLAS1, is based on the expression of the $g f p$ gene under the control of the ars promoter and the arsR gene of $S$. aureus plasmid pI258. Several bacterial biosensors for arsenic have been developed using various reporter genes, such as lacZ, luxAB, and luc [21-24]. Although the colorimetric enzyme assay and bioluminescence have been very successful as a reporter for arsenic detection, these methods require the addition of exogenous substrates or cofactors. In addition, these assays require additional experimental steps before measuring signals. The gene for GFP from the jellyfish Aequoria victoria [25] is used increasingly as a reporter gene, although it has not been used extensively as a reporter for measuring biologically relevant concentrations of pollutants. The use of $g f p$ as a reporter gene gives this biosensor the advantages associated with GFP, such as the ability to use fluorescence without the need for exogenous enzymes, substrates, or cofactors and the ability to use fluorometry and fluorescence microscopy to monitor gene expression for assessing the bioavailability of the metal, as well as providing a method that can be monitored noninvasively in living cells. Moreover, the use of GFP as a reporter protein in the bacterial biosensing system alleviates the need for extra experimental steps, such as centrifugation, cell lysis, $\mathrm{pH}$ adjustment, and subsequently, kinetic enzyme activity measurements. However, on the other hand, one of the possible drawbacks with measuring GFP in whole cells as it is being produced is that its chromophore forms slowly in the presence of molecular oxygen. As a consequence, any direct measurement is probably an estimate of the total GFP present, because a portion of the GFP in whole cells might not yet have become fluorescent.

\section{Characterization of DH5 $\alpha$ (pVLAS1) biosensor}

Induction patterns of DH5 $\alpha$ (pVLAS1) differ slightly from those observed in other reports. Tauriainen et al. [24] tested the sensor plasmid with different host strains. They reported that the biosensor was strongly induced by $\mathrm{As}(\mathrm{III}), \mathrm{Sb}(\mathrm{III})$, and $\mathrm{Cd}(\mathrm{II})$ and only slightly induced by $\mathrm{As}(\mathrm{V})$ in both $S$. aureus RN4220 and Bacillus subtilis BR151. In contrast, $\mathrm{As}(\mathrm{III}), \mathrm{Sb}(\mathrm{III}), \mathrm{Cd}(\mathrm{II})$, and $\mathrm{As}(\mathrm{V})$ were not strong inducers using E. coli MC1061 as host strain in their studies. Robust induction of fluorescence was observed for As(III), As(V), and $\mathrm{Sb}(\mathrm{III})$ from our studies, whereas $\mathrm{Cd}$ (II) was not an effective inducer to the biosensor under our experimental conditions. Because the bacterial sensor cells contain a chromosomally encoded arsenate reductase [28], they also react to As(V). The relative high sensitivity of DH5 $\alpha$ (pVLAS1) for As(V) may result from the higher expression of chromosomal arsenate reductase enzyme of E. coli [17]. Additionally, gfp might be a more sensitive reporter gene than $l u c$, which was used in the study of by Tauriainen et al. The pattern of induction of DH5 $\alpha$ (pVLAS1) was similar to those of other biosensor strains, which were developed from plasmid R773 in E. coli [21-23].

In addition to use of the host strains, it has been reported that several factors might influence the expression of biosensors. These include incubation time, medium composition, growth phase of harvested bacteria, and amount of bacteria per measurement [24]. In our studies, the sensitivity of the biosensor was not greatly affected by the growth phase of harvested bacteria or by the medium composition (data not shown). The effect of the induction time was investigated by incubating the bacteria with $\mathrm{As}(\mathrm{III}), \mathrm{As}(\mathrm{V})$, and $\mathrm{Sb}(\mathrm{III})$ for various time periods. The responses of the bacterial DH5 $\alpha$ (pVLAS1) toward As(III), As(V), and Sb (III) were time dependent. With an increase in the induction time, the fluorescent intensity also increased. Moreover, the sensitivity of the system was contingent on the time used for inducing the cells. For example, for an induction period of $8 \mathrm{~h}$, the bacteria could sense $\mathrm{As}(\mathrm{III}), \mathrm{As}(\mathrm{V})$, and $\mathrm{Sb}$ (III) at $0.1 \mu \mathrm{M}$. When the induction period was reduced, we observed a decrease in the detection limits. Therefore, if very sensitive detection is needed, it could be achieved by employing longer incubation times. For assay development, a 2-h induction period was chosen, because the green fluorescent signal obtained during this time period was sufficiently high. Moreover, a 2-h incubation also allows complete formation of the GFP fluorophore.

The response of the bacterial sensing system toward metal ions was determined by incubating cells with metal ions for various concentrations before the assay, and subsequent doseresponse curves were generated. The fluorescent intensity increased with increasing concentrations of As(III), As(V), and $\mathrm{Sb}$ (III) ions to a certain level. With concentrations lower than the detection limits, binding of $\operatorname{ars} R$ to the $\operatorname{ars} \mathrm{O} / \mathrm{P}$ sequence repressed transcription and translation of $r s$-GFP. Addition of $\mathrm{As}(\mathrm{III}), \mathrm{As}(\mathrm{V})$, and $\mathrm{Sb}(\mathrm{III})$ ions removed the repression of $r s-$ GFP in the cells.

The minimum concentration of the effector required for $g f p$ expression varies from one effector to another. For As(III), the 
Table 2. Comparison of detection limits to $\mathrm{As}(\mathrm{III}), \mathrm{As}(\mathrm{V})$, and $\mathrm{Sb}(\mathrm{III})$ by biosensor bacteria

\begin{tabular}{|c|c|c|c|c|c|c|}
\hline Strain & Promoter & Plasmid & Reporter & Induction time (h) & Detection limit & Reference \\
\hline \multicolumn{7}{|l|}{ As(III) } \\
\hline E. coli ${ }^{\mathrm{a}} \mathrm{MC} 1061$ & S. aureus $^{\mathrm{b}}(\mathrm{pl} 258)$ & pT0031 & $l u c$ & 2 & $3.3 \mu \mathrm{M}$ & [24] \\
\hline S. aureus RN4420 & S. aureus (pl258) & pT0031 & luc & 2 & $0.1 \mu \mathrm{M}$ & [24] \\
\hline B. subtilis B $^{\mathrm{BR}} 151$ & S. aureus (pl258) & pT0031 & luc & 2 & $3.3 \mu \mathrm{M}$ & [24] \\
\hline E. coli JM109 & E. coli $(\mathrm{R} 773)$ & pBGD23 & lacZ & 17 & $0.1 \mu \mathrm{M}$ & [21] \\
\hline E. coli $\mathrm{DH} 5 \alpha$ & E. coli $(\mathrm{R} 773)$ & pMV-arsR & $\operatorname{lu} x A B$ & 1 & $0.1 \mu \mathrm{M}$ & [23] \\
\hline E. coli $\mathrm{DH} 5 \alpha$ & E. $\operatorname{coli}(\mathrm{R} 773)$ & pJAMA-arsR & lacZ & 1 & $0.1 \mu \mathrm{M}$ & {$[23]$} \\
\hline E. coli $\mathrm{DH} 5 \alpha$ & E. coli $(\mathrm{R} 773)$ & pPR-arsR & $g f p$ & 1 & $0.1 \mu \mathrm{M}$ & [23] \\
\hline E. coli $\mathrm{DH} 5 \alpha$ & S. aureus (pI258) & pVLASI & $g f p$ & 2 & $0.4 \mu \mathrm{M}$ & Present study \\
\hline E. coli $\mathrm{DH} 5 \alpha$ & S. aureus (pI258) & pVLASI & $g f p$ & 8 & $0.1 \mu \mathrm{M}$ & Present study \\
\hline \multicolumn{7}{|l|}{ As $(V)$} \\
\hline E. coli MC1061 & S. aureus (pI258) & pT0031 & luc & 2 & $33 \mu \mathrm{M}$ & [24] \\
\hline S. aureus RN4420 & S. aureus (pI258) & pT0031 & $l u c$ & 2 & $100 \mu \mathrm{M}$ & {$[24]$} \\
\hline B. subtilis $\mathrm{BR} 151$ & S. aureus (pI258) & pT0031 & luc & 2 & $330 \mu \mathrm{M}$ & [24] \\
\hline E. coli JM109 & E. coli $(\mathrm{R} 773)$ & pBGD23 & $l a c Z$ & 2 & $10 \mu \mathrm{M}$ & {$[21]$} \\
\hline E. coli JM109 & E. coli $(\mathrm{R} 773)$ & pBGD23 & lacZ & 17 & $1 \mu \mathrm{M}$ & [21] \\
\hline E. coli $\mathrm{DH} 5 \alpha$ & S. aureus (pI258) & pVLASI & $g f p$ & 2 & $1 \mu \mathrm{M}$ & Present study \\
\hline E. coli $\mathrm{DH} 5 \alpha$ & S. aureus (pI258) & pVLASI & $g f p$ & 8 & $0.1 \mu \mathrm{M}$ & Present study \\
\hline \multicolumn{7}{|l|}{$\mathrm{Sb}(\mathrm{III})$} \\
\hline E. coli MC1061 & S. aureus (pI258) & pT0031 & $l u c$ & 2 & $3.3 \mu \mathrm{M}$ & [24] \\
\hline S. aureus RN4420 & S. aureus (pI258) & pT0031 & $l u c$ & 2 & $33 \mathrm{nM}$ & [24] \\
\hline B. subtilis BR151 & S. aureus (pI258) & pT0031 & luc & 2 & $330 \mathrm{nM}$ & [24] \\
\hline E. coli JM109 & E. coli (R773) & pBGD23 & $\operatorname{lac} Z$ & 0.5 & $10 \mu \mathrm{M}$ & [21] \\
\hline E. coli JM109 & E. coli $(\mathrm{R} 773)$ & pBGD23 & lacZ & 2 & $5 \mu \mathrm{M}$ & [21] \\
\hline E. coli JM109 & E. coli $(\mathrm{R} 773)$ & pBGD23 & lacZ & 17 & $0.1 \mu \mathrm{M}$ & {$[21]$} \\
\hline E. coli $\mathrm{DH} 5 \alpha$ & S. aureus (pI258) & pVLASI & $g f p$ & 2 & $0.75 \mu \mathrm{M}$ & Present study \\
\hline E. coli $\mathrm{DH} 5 \alpha$ & S. aureus (pI258) & pVLASI & $g f p$ & 8 & $0.1 \mu \mathrm{M}$ & Present study \\
\hline
\end{tabular}

${ }^{a}$ Escherichia coli.

${ }^{\mathrm{b}}$ Staphylococcus aureus.

${ }^{ }$Bacillus subtilis.

minimum concentration required for $\mathrm{As}$ (III) detection obtained here was on the same order of sensitivity level as those of the similar biosensor systems [21,23,24]. Our results showed that the lowest detectable concentrations for As(III) with the DH5 $\alpha$ (pVLAS1) were 0.4 and $0.1 \mu \mathrm{M}$ with 2- and 8-h exposure, respectively. At higher As(III) concentrations, our results showed a statistically significant $(p<0.05)$ increase in fluorescent intensity, but at low concentration $(<0.4 \mu \mathrm{M}$ for $2 \mathrm{~h}$ and $<0.1 \mu \mathrm{M}$ for $8 \mathrm{~h}$ ), the fluorescent intensity was not statistically different $(p>0.05)$ from that of the As(III) negative control. For As(V), the detection limits obtained here are one to three orders of magnitude lower than those reported previously in other cell-based sensing protocols for this metal ion $[21,24]$. Our results showed that the minimum concentration required for $\mathrm{As}(\mathrm{V})$ detection was 1 and $0.1 \mu \mathrm{M}$ with a 2 - and 8-h induction period, respectively. The response obtained for $\mathrm{Sb}$ (III) ions was similar to those obtained for $\mathrm{As}(\mathrm{III})$ and $\mathrm{As}(\mathrm{V})$, and the detection limit for $\mathrm{Sb}$ (III) was 0.75 and 0.1 $\mu \mathrm{M}$ with a 2- and 8-h induction period, respectively. The comparison of bacterial biosensors responded to As(III), As(V), and $\mathrm{Sb}$ (III) is shown in Table 2. Several factors influence the sensitivity of the biosensor for the detection of these effectors. These include the exposure time, the ars plasmid used, the analytical detection method employed, the reporter gene used, and the choice of bacterial strains. Moreover, methods used to define a detection limit for detecting effectors vary among different researchers, which may contribute to slightly different values for the minimum detection limit.

Field testing environmental groundwater samples using a DH5 $\alpha$ (pVLAS1) biosensor approach

The amount of arsenic contamination measured by the MOEA using atomic absorption spectrophotometry was com- pared to those measured using the biosensor. For both wells, YL6 and YL7, the groundwater concentrations of As(III) equivalent estimated by the biosensor assay compared closely to those found in the MOEA report. The measured amount of As(III) equivalent by the biosensor assay was slightly lower than the arsenic concentration reported by MOEA. This finding is not unexpected, because the MOEA report measured the amount of total arsenic instead of As(III) concentration. Additionally, in contrast to the conventional chemicals analysis of total arsenic, the biosensor described here primarily measured the bioavailable arsenic. Furthermore, adsorption of arsenic to small particulates within groundwater samples may decrease the bioavailability of arsenic to the biosensor. Although the use of biosensor accurately measured the bioavailable arsenic in the contaminated groundwater in the present study, it was not able to distinguish the arsenic species within the groundwater samples. However, As(III) is the major arsenic species of groundwater in shallow wells, including YL6 and YL7, in the blackfoot disease region of Yun-Lin County (ChenWuing Liu, Department of Bioenvironmental Systems Engineering, National Taiwan University, Taiwan, Republic of China, personal communication). Therefore, we are able to estimate the amounts of arsenic, mostly as As(III), from groundwater obtained from the shallow-wells YL6 and YL7 by using the derived standard curve of As(III).

In summary, we describe the construction, laboratory characterization, and environmental sample testing of a specific biosensor for the detection of $\mathrm{As}(\mathrm{III}), \mathrm{As}(\mathrm{V})$, and $\mathrm{Sb}(\mathrm{III})$. Moreover, the present study demonstrates that the nonpathogenic DH5 $\alpha$ (pVLAS1) is useful and applicable in determining the bioavailability of arsenic with high sensitivity in contaminated groundwater samples. However, one potential limitation 
with this method for the testing of environmental samples is that even though the sensitivities of the dose-response curve for $\mathrm{As}(\mathrm{III}), \mathrm{As}(\mathrm{V})$, and $\mathrm{Sb}(\mathrm{III})$ are different, we cannot distinguish between these metals using this system. Moreover, in contaminated sites, many different chemicals other than the inducer compounds could be toxic to or interact with E. coli, thereby causing inhibitory effects. However, it is impossible to determine the effect of these chemicals, even if the chemicals have been identified by chemical analysis because of the numerous potential combinations of these chemicals. Furthermore, components of the environmental sample, such as high salt and high $\mathrm{pH}$ values, also could inhibit the $g f p$ expression of the biosensor. Possible inhibitory effects can be addressed by adding a known amount of an optimal inducer (in this case, As(III)) to the unknown samples and then measuring induction differences. Despite these limitations, the bacterial biosensor based on pVLAS1-GFP represents a rapid, easy to perform, and inexpensive alternative to the conventional atomic absorption spectroscopic method for arsenic detection and measurement. Additionally, because field samples often contain unidentified components, the biosensor can be useful in the screening of unknown contaminants in environmental samples because of its specific selectivity toward As(III), As(V), and $\mathrm{Sb}$ (III). Moreover, the GFP-based bacterial biosensor can be useful for environmental analysis, providing information about the bioavailability of metals, which is the most relevant information when assessing the environmental and/or potential biological impact of a contaminant. It also can be useful for studying environmental conditions, which can influence metal bioavailability. Unfortunately, the issue of bioavailability is not easily addressed by the traditional analytical methods. Results from chemical analysis are very precise, but the bioavailability of the metals is not taken into account. This is a particular concern with respect to toxic metals. Therefore, the bacterial biosensors complement rather than replace traditional analytical methods, providing critical data that can be useful in risk assessment and helpful in planning and evaluation of the remediation needs of arsenic-contaminated sites.

Acknowledgement-We express thanks to Chen-Wuing Liu at the Department of Bioenvironmental Systems Engineering, National Taiwan University, Taiwan, Republic of China, for assistance in obtaining groundwater samples and in providing results of contamination testing of water from YL6 and YL7. We thank Steven E. Lindow, University of California-Berkeley, California, USA, for providing the pPROBE$\mathrm{NT}^{\prime}$ vector.

\section{REFERENCES}

1. Tchounwou PB, Wilson BA, Ishaque A. 1999. Important considerations in the development of public health advisories for arsenic and arsenic containing compounds in drinking water. Rev Environ Health 14:1-19.

2. Agency for Toxic Substances and Disease Registry. 2000. Toxicological profile for arsenic. PB/2000/108021. U.S. Department of Health and Human Services, Public Health Service, Washington, DC.

3. National Research Council. 1999. Arsenic in Drinking Water. National Academy Press, Washington, DC.

4. Abernathy CO, Liu YP, Longfellow D, Aposhian HV, Beck B, Fowler B, Goyer R, Menzer R, Rossman T, Thompson C, Waalkes M. 1999. Arsenic: Health effects, mechanisms of actions, and research issues. Environ Health Perspect 107:593-597.
5. Vahter M, Concha G. 2001. Role of metabolism in arsenic toxicity. Pharmacol Toxicol 89:1-5.

6. Lerman SA, Clarkson TW, Gerson RJ. 1983. Arsenic uptake and metabolism by liver cells is dependent on arsenic oxidation state. Chem-Biol Interact 45:401-406.

7. Del Razo LM, Styblo M, Cullen WR, Thomas DJ. 2001. Determination of trivalent methylated arsenicals in biological matrices. Toxicol Appl Pharmacol 174:282-293.

8. Flynn HC, Meharg AA, Bowyer PK, Paton GI. 2003. Antimony bioavailability in mine soils. Environ Pollut 124:293-100.

9. Filella M, Belzile N, Chen YW. 2002. Antimony in the environment: A review focused on natural waters. I. Occurrence. EarthSci Rev 57:125-176.

10. De Boeck M, Kirsch-Volders M, Lison D. 2003. Cobalt and antimony: Genotoxicity and carcinogenicity. Mutat Res 533:135152.

11. Lintschinger J, Michalke B, Schulte-Hostede S, Schramel P. 1998. Studies on speciation of antimony in soil contaminated by industrial activity. Int J Environ Anal Chem 72:11-25.

12. Patterson TJ, Ngo M, Aronov PA, Reznikova TV, Green PG, Rice RH. 2003. Biological activity of inorganic arsenic and antimony reflects oxidation state in cultured human keratinocytes. Chem Res Toxicol 16:1624-1631.

13. Kaur P, Rosen BP. 1992. Plasmid-encoded resistance to arsenic and antimony. Plasmid 27:29-40.

14. Rosen BP. 1999. The role of efflux in bacterial resistance to soft metals and metalloids. Essays Biochem 34:1-15.

15. Mukhopadhyay R, Rosen BP, Phung le T, Silver S. 2002. Microbial arsenic: From geocycles to genes and enzymes. FEMS Microbiol Rev 26:311-25.

16. Owolabi JB, Rosen BP. 1990. Differential mRNA stability controls relative gene expression within the plasmid-encoded arsenical resistance operon. J Bacteriol 172:2367-2371.

17. Diorio C, Cai J, Marmor J, Shinder R, DuBow MS. 1995. An Escherichia coli chromosomal ars operon homolog is functional in arsenic detoxification and conserved in gram-negative bacteria. J Bacteriol 177:2050-2056.

18. Chen CM, Misra T, Silver S, Rosen BP. 1986. Nucleotide sequence of the structural genes for an anion pump. The plasmid-encoded arsenical resistance operon. J Biol Chem 261:15030-15038.

19. San Francisco MJD, Hope CL, Owolabi JB, Tisa L S, Rosen BP. 1990. Identification of the metalloregulatory element of the plasmid-encoded arsenical resistance operon. Nucleic Acids Res 18: 619-624.

20. Ji G, Silver S. 1992. Regulation and expression of the arsenic resistance operon from Staphylococcus aureus plasmid pI258. J Bacteriol 174:3684-3694.

21. Scott DL, Ramanathan S, Shi W, Rosen BP, Daunert S. 1997. Genetically engineered bacteria: Electrochemical sensing systems for antimonite and arsenite. Anal Chem 69:16-20.

22. Ramanathan S, Shi W, Rosen BP, Daunert S. 1997. Sensing antimonite and arsenite at the subattomole level with genetically engineered bioluminescent bacteria. Anal Chem 69:3380-3384.

23. Stocker J, Balluch D, Gsell M, Harms H, Feliciano J, Daunert S, Malik KA, van der Meer JR. 2003. Development of a set of simple bacterial biosensors for quantitative and rapid measurements of arsenite and arsenate in potable water. Environ Sci Technol 37: 4743-4750.

24. Tauriainen S, Karp M, Chang W, Virta M. 1997. Recombinant luminescent bacteria for measuring bioavailable arsenite and antimonite. Appl Environ Microbiol 63:4456-4461.

25. Chalfie M, Tu Y, Euskirchen G, Ward WW, Prasher DC. 1994. Green fluorescent protein as a marker for gene expression. Science 263:802-805.

26. Miller WG, Leveau JHJ, Lindow SE. 2000. Improved $g f p$ and inaZ broad-host-range promoter-probe vectors. Mol Plant-Microbe Interact 13:1243-1250.

27. Simons RW, Houman F, Kleckner N. 1987. Improved single and multicopy lac-based cloning vectors for protein and operon fusions. Gene 53:85-96.

28. Carlin A, Shi W, Dey S, Rosen BP. 1995. The ars operon of Escherichia coli confers arsenical and antimonial resistance. $J$ Bacteriol 177:981-986. 